\title{
Financial Performance Analysis of the Jordanian Arab Bank by Using the DuPont System of Financial Analysis
}

\author{
Dr Ahmed Arif Almazari \\ Department of Business Administrative Sciences, Finance Section \\ King Saud University, RCC \\ E-mail: aalmazari@ksu.edu.sa / ahmadarif26@hotmail.com
}

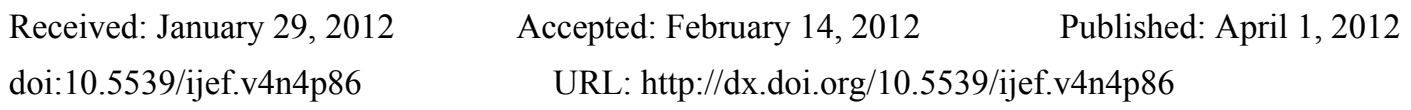

\begin{abstract}
This study attempts basically to measure the financial performance of the Jordanian Arab commercial bank for the period 2000-2009 by using the DuPont system of financial analysis which is based on analysis of return on equity model. The return on equity model disaggregates performance into three components: net profit margin, total asset turnover, and the equity multiplier. Arab bank is one of the largest financial institutions in the Middle East and is ranked amongst the largest international financial institutions. The bank witnessed a continuation of challenges brought on by the global financial crisis. It was found that the financial performance of Arab Bank is relatively steady and reflects minimal volatility in the return on equity. Net profit margin and total asset turnover exhibit relative stability for the period from 2001 to 2009. The equity multiplier also show almost stable indicators for the period from2001-2005 and the ratios declined from 2006-2009 which indicates that the Arab bank had less financial leverage in the recent years, which means the bank is relying less on debt to finance its assets.
\end{abstract}

Keywords: DuPont, Return on equity, Net profit margin, Equity multiplier, Asset utilization

\section{Introduction}

For any business in the private sector there are numerous of models to describe how well the business is running. Among these the DuPont model was created in the early 1900s but is still a model valid to use for assessment of the profitability. Using the DuPont model for risk analysis is not very common but if you as a risk analysis specialist wants to talk the language of the business, it can be valuable to you.

The model was created by F. Donaldson Brown who came up with the model when he was assigned to clean up the finances in General Motors and has ever since been an important model for financial analysis. Remarkably it has not been used in the security community for risk prioritization or impact analysis. The original DuPont method of financial ratio analysis was developed in 1918 by an engineer at DuPont who was charged with understanding the finances of a company that DuPont was acquiring. He noticed that the product of two often-computed ratios, net profit margin and total asset turnover, equals return on assets (ROA). The elegance of ROA being affected by a profitability measure and an efficiency measure led to the DuPont method becoming a widely-used tool of financial analysis Liesz, (2002). In the 1970's, emphasis in financial analysis shifted from ROA to return on equity (ROE), and the DuPont model was modified to include the ratio of total assets to equity. Regarding this fact the researcher have taken the challenge to use this model for Arab bank the largest bank in Jordan.

Banks and other financial institutions are a unique set of business firms whose assets and liabilities, regulatory restrictions, economic functions and operating make them an important subject of research, particularly in the conditions of the emerging financial sectors. Banks' performance monitoring, analysis and control needs special analysis in respect to their operation and performance results from the viewpoint of different audiences, like investors/owners, regulators, customers/clients, and management themselves. Different versions of financial ratio analysis are used for the bank performance analysis using financial statement items as initial data sources. The usage of a modified version of DuPont financial ratio analysis is discussed in the article. Empirical results of the Arab commercial banking system performance analysis are also presented in the article from (2000-2009).

As with Little, et al (2009), the modified DuPont model of financial ratio analysis is used to identify the drivers of financial success under alternative business strategies. Firms in the retail industry are categorized according to their high/low relative net operating income to sales and operating asset turnover ratios. Firms with high relative net operating income to sales and low relative operating asset turnover are assumed to be pursuing a differentiation 
strategy and those with high relative operating asset turnover and low relative net operating income to sales are assumed to be pursuing a cost leadership strategy. The performance variable used is return on net operating assets.

In this article, the researcher present one of the possible approaches to such financial analysis using the modified version of DuPont analysis see Cole, (1973), which is similar to Dietrich's (1996) approach, and the novel matrix approach which is was firstly presented in Vensel, (1997) see also Vensel, (2001).

This study attempts basically to measure the financial performance of the Jordanian Arab commercial bank. As a matter of fact banks are classified according to their financial characteristics and financial indicators which can be presented from the banks financial statements. The other objectives will attempt to find out the ratios of net profit margin, asset utilization, equity multiplier and return on equity from the period of 2000-2009.

Net profit margin ratios are an indication of how effective a company is at cost control. The higher the net profit margin is, the more effective the company is at converting revenue into actual profit. This study also aims at finding out the asset utilization of the Arab bank for the same period. The asset utilization ratio calculates the total revenue earned for every dollar of assets a company owns. This ratio indicates a company's efficiency in using its assets. An equity multiplier analysis is used in this study which is a formula used to calculate a company's financial leverage, and the debt a company uses to finance its assets. The equity multiplier is also a kind of leverage ratio, which is any method of determining a company's financial leverage. It can be calculated by looking at a company's balance sheet and dividing the total assets by the total stockholder equity. One of the most important profitability metrics is return on equity (ROE). Return on equity reveals how much profit a company earned in comparison to the total amount of shareholder equity found on the balance sheet. A business that has a high return on equity is more likely to be one that is capable of generating cash internally. For the most part, the higher a company's return on equity compared to its industry, the better.

The paper is organized as follows. Section I introducing the importance and objectives of study. Section II discusses the relevant literature review. Section III gives a brief overview on the Arab Jordanian banking system-the most important recent developments in the bank .DuPont financial ratio analysis modified methodology and empirical results of the banking system performance are discussed in Section IV. In Section V The paper ends with some concluding remarks.

\section{Literature Review}

In order to more effectively evaluate operational managers, Nissim \& Penman (2001) suggest using a modified version of the traditional DuPont model in order to eliminate the effects of financial leverage and other factors not under the control of those managers. Using operating income to sales and asset turnover based on operating assets limits the performance measure of management to those factors over which management has the most control. The modified DuPont model has become widely recognized in the financial analysis literature. See, for example, Pratt \& Hirst (2008), Palepu \& Healy (2008), and Soliman (2008). In addition, Soliman (2004) found that industry-specific DuPont multiplicative components provide more useful valuation than do economy-wide components, suggesting that industry-specific ratios have increased validity.

In carrying out bank performance analysis, it is important to emphasize that banks differ in their corporate governance from firms in other, less regulated industries. These differences, in turn, present their own challenges for bank managers, regulators, depositors, investors, and other stakeholders. "Bank managers live in a more complex environment than their peers in industry due to bank regulations. In addition to the demands placed on them by shareholders, regulators have strong incentives to influence managerial action, and this may be in conflict with shareholder demands" Harm (2002). Governance is a set of mechanisms with which the providers of capital and other stakeholders are defending their interests against the firm. The firm is run by managers, and this a point where conflicts of interests starts. An excellent survey of recent literature (both theoretical and empirical) is also presented by Harm (2002).

Macey and O'Hara (2003) argue that bank officers and directors should be held to broader (if not higher) set of standards than their counterparts in less regulated non- financial firms, and banks pose special corporate governance problems. Kose and Qian (2003) consider another important theme in the corporate governance of banks - the effect of the incentive features built into the compensation schemes of bank mangers. Adams and Mehran (2003) focus also on the differences between the corporate governance of banks and manufacturing firms and support the theory that governance structures are industry-specific. In general, the components of firm's governance structure are determined by various different factors, which all will influence also performance analysis aims and techniques: the nature and structure of firm's assets and liabilities (leverage, share of financial assets, business risk, cash- flow patterns), firm size, industry, regulations, etc. 
Various measures of rates of return are used mainly for that purpose. We fully agree with the opinion that "Relaying too heavily on just a few indicators of bank profitability can be misleading. While ROA, ROE, and interest margin (and non interest expenses) to gross income remain the key measures, they should ideally be supplemented by the analysis of other operating ratios" Sundararajan, et al (2002).

Brigham and Houston, (2001) The modified model was a powerful tool to illustrate the interconnectedness of a firm's income statement and its balance sheet, and to develop straight-forward strategies for improving the firm's ROE.

Hawawini and Viallet (1999) offered yet another modification to the DuPont model. This modification resulted in five different ratios that combine to form ROE. In their modification they acknowledge that the financial statements firms prepare for their annual reports (which are of most importance to creditors and tax collectors) are not always useful to managers making operating and financial decisions.

\section{Arab Bank}

Arab bank is one of the largest financial institutions in the Middle East. Established in Jerusalem in Palestine in 1930 as a small bank, it has evolved into a group with the largest worldwide Arab network with over 500 branches in 30 countries on five continents, participating in financial markets and centers.

Since its establishment in Jerusalem on May 21, 1930 as Arab Bank Limited, the Arab Bank has continued to grow and improve. On January 31, 1990, the name changed to Arab Bank plc in accordance with Section 318 of the Jordanian Companies Act \# 1 of 1989.Arab Bank was the first public shareholding company listed in the Amman Stock Exchange in 1978.

The Bank is constantly improving its disclosure levels and introducing higher levels of transparency through its financial statements, enabling both shareholders and customers to appreciate its ever-growing earning power, its low risk level, and its strong financial position.

The bank works in developing Arab economies through financing strategic infrastructural projects across the Middle East /North Africa region (MENA). With Headquarters based in Amman, Jordan, the Arab Bank constitutes the first private sector financial institution in the Arab World.

The Arab Bank is ranked amongst the largest international financial institutions, with a rating of A- from Fitch, Afrom Standard \& Poor and A3 from Moody's. The bank has a capital base of over USD 5.5 Billion and Total Assets of over USD 50 billion. Pretax Income reached over USD 1 Billion in 2008, with a Net Income of USD 850 Million for the year 2008.

The year 2010 witnessed a continuation of challenges brought on by the global financial crisis, which started more than two years ago at an unprecedented scale, with its prolonged negative repercussions deeply impacting all the world's economies, affecting countries, institutions and individuals alike. Many countries around the world are still experiencing difficult economic conditions and the work and investment environments still need more time before emerging out of the current status. The consequences of the global financial crisis continue to have a negative impact on the various aspects of economic and financial environments in most parts of the world. In addition, the reach of the crisis continues to expand carrying increased losses for countries and institutions and threaten to further poverty and unemployment at an international level.(Arab bank Annual Reports 2010).

\section{A Financial Analysis Model for Financial Institutions}

Saunders (2000) provides a model of financial analysis for financial institutions based on the DuPont system of financial analysis return on equity model. The return on equity model disaggregates performance into three components: net profit margin, total asset turnover, and the equity multiplier. The profit margin allows the financial analyst to evaluate the income statement and the components of the income statement. Total asset turnover allows the financial analyst to evaluate the left-hand side of the balance sheet: assets. The equity multiplier allows the financial analyst to evaluate the right-hand side of the balance sheet: liabilities and owners equity.

Return on equity analysis provides a system for planning as well as analyzing financial institution performance. The profit margin allows the analyst to develop a pro forma income statement. That is, net income is equal to revenues less expenses. Thus, the financial planner can determine the revenue level necessary to achieve the net income target. The total asset turnover ratio allows the analyst to project the total asset level necessary to generate the projected revenue level. The total asset requirement can be used to project the pro forma levels of all of the asset accounts. The fundamental equation of accounting is that assets equal liabilities plus owners equity. Thus, the equity multiplier ratio can be used to project the pro forma financial needs and the financial structure of the financial institution. 
Return on equity, ROE, is first decomposed into return on asset, ROA, and the equity multiplier, EM. Return on assets is decomposed into net profit margin and total asset turnover:

$$
\begin{aligned}
& \text { ROE }=(\text { ROA })(\text { EM }) \\
& \text { ROA }=(\text { NPM })(\text { TAT })
\end{aligned}
$$

Where,

ROE $=$ return on equity

EM = the equity multiplier

TAT $=$ total asset turnover

$$
\begin{aligned}
& \text { ROA }=\text { return on assets } \\
& \text { NPM }=\text { net profit margin }
\end{aligned}
$$

Return on equity is net income divided by total equity capital and return on assets is net income divided by total assets. The equity multiplier is the ratio of total assets and total equity capital.

ROE $=($ NI $) /($ TEC $)$
ROA $=($ NI $) /($ TA $)$
EM $=($ TA $) /($ TEC $)$

Where,

$\mathrm{NI}=$ net income

TA $=$ total asset

TEC $=$ total equity capital

\section{DuPont Model}

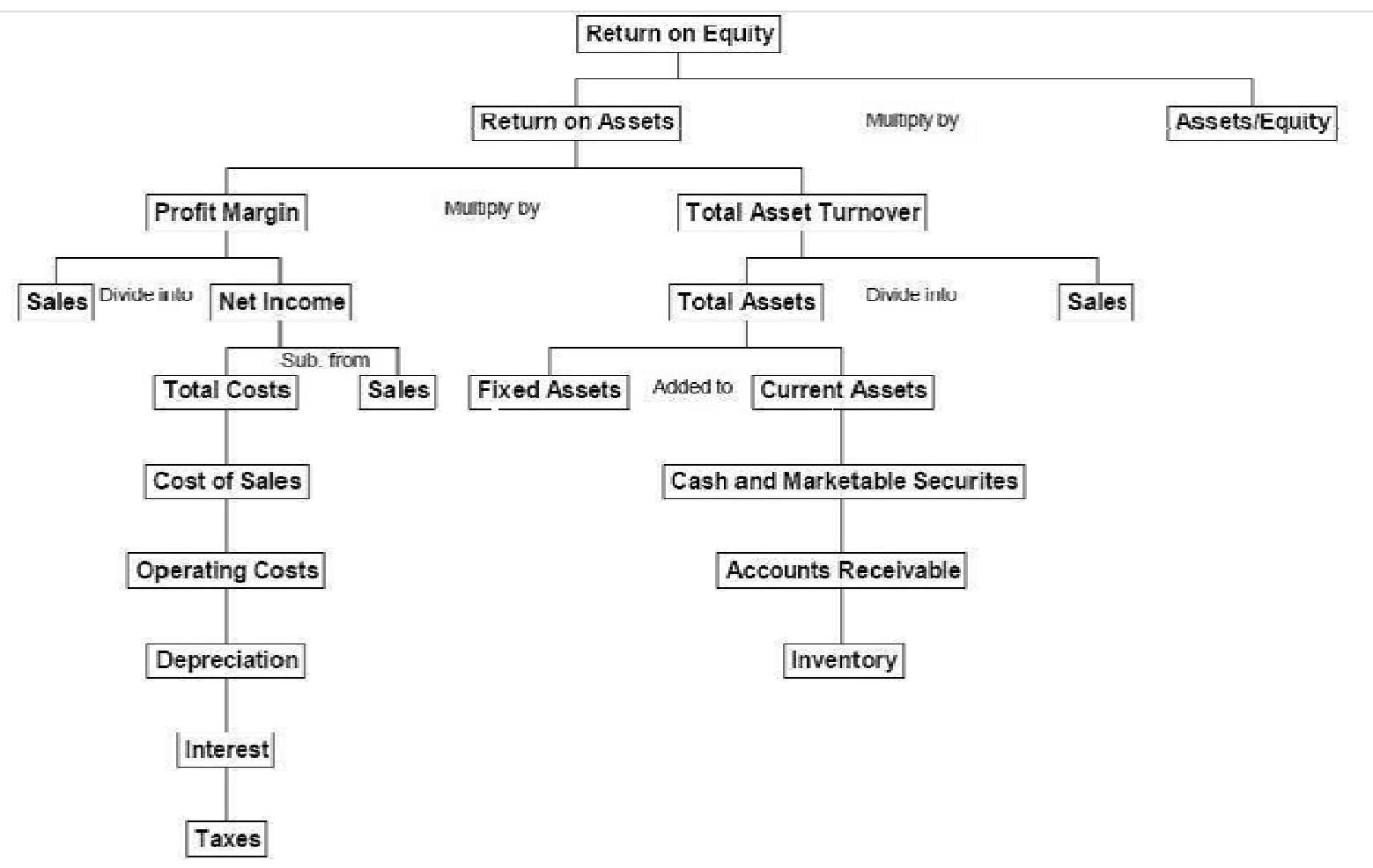

Net profit margin can be decomposed into both the income and expense components. Total asset turnover can be decomposed into interest and non-interest income components

The net profit margin ratio can be used to develop a pro forma income statement. The total asset turnover ratio can be used to estimate the pro forma left-hand side of the balance sheet. The equity multiplier ratio can be used to estimate the pro forma right-hand side of the balance sheet. Thus, the DuPont system of financial analysis can be used to construct a financial plan for the bank. The DuPont system of financial analysis provides a means for the firm to monitor performance through the planning period and to post-audit the planning process. 


\section{A. Balance Sheet Items}

Arab Bank has four major categories of assets - cash, customer loans, securities and deposits as well as fixed/other assets. Cash has fluctuated from Jordanian Dinars (J.D) 1.4 billion in 2000 to a high of JD 4.0 in 2009 with an average of RM 2.3 billion (Note:1 Jordanian Dinar is equal to 1.43 USD). The customer loans account has decreased from a high of JD 3.33 billion in 2000 to JD2.78 billion in 2009 and an average of billion JD 3.57. Securities and deposits are highest at JD 8.67 billion, in 2000 and increased steadily to billion JD10.57 in 2005 before increasing to JD 15.76 billion in 2009 and with an average of billion JD 11.41. Fixed assets increased from a low of billion JD 0.43 in 2000 to billion JD 0.56 in 2009 and with an average of 0.48 JD. Arab Bank has three major liability accounts - corporate and retail deposits, other liabilities and shareholder funds. Corporate and retail deposits increased from billion JD12.34 in 2000 to the billion JD 18.78 in 2009 with an average level of 15.03 JD billion. Other liabilities decreased from RM 1.06 billion in 2000 to JD 0.52 billion in 2009 with an average of JD 0.56 billion. Shareholder funds increased from JD .45 billion in 2000 to JD 1.86 billion in 2005 and then increased to JD 3.8 billion in 2009 with an average 2.17.

\section{B. Income Statement Items}

Arab bank has three sources of income - interest income, non-interest income and gains, and net income. Interest income has fluctuated from JD 894 million in 2000 to JD 724 million in 2005 and then increased to JD 917 million in 2009 with an average of JD 818 million. Net income from non-interest income and gains increased from JD 129 million in 2000 to JD184 in 2003 and fluctuated during 2005 to 2007 ending at JD 246 million in 2009. Net income increased from JD 130 million in 2000 to JD 200 million in 2005 and ended the period at JD 250 million in 2009.

Arab bank has four expense categories: interest expense, provisions for bad loans, overhead costs, and income tax. Interest expense has fluctuated from JD 633 million in 2000 to JD 369 million in 2005 to JD 398 million in 2009 with an average of JD 443 million. Provision for bad loans decreased from JD 34 million in 2000 to JD 6 million in 2005 and increased to JD 85 million in 2009. Overhead costs increased from JD 195 million in 2000 to JD 320 million in 2005 and increased to JD 354 million in 2009. Income tax has increased from JD 31 million in 2000 to JD 75 million in 2009 with an average JD 51.5 million.

\section{Discussion of Financial Ratios}

As a percent of total assets of Arab Bank, cash averages $12.71 \%$ of total assets with a high of $17.34 \%$ in 2009 and a low of $10.16 \%$ in 2000 . Customer loans average $20.93 \%$ of total assets with a high of $26.26 \%$ in 2002 and a low of $12.05 \%$ in 2009 . Net securities average $63.64 \%$ with a high of $69.65 \%$ in 2008 and a low of $59.26 \%$ in 2002 . Fixed assets average $2.71 \%$ with a high of $3.10 \%$ in 2000 and with a low of $2.38 \%$ in 2004 . Corporate and retail deposits average $85.14 \%$ with a low of $80.64 \%$ in 2006 and with a high of $89.18 \%$ in 2001 . Other liabilities average $3.34 \%$ with a low of $2.25 \%$ in 2009 and with a high of $7.62 \%$ in 2000 . Shareholder funds average $11.51 \%$ with a low of $3.23 \%$ in 2000 and with a high of $16.79 \%$ in 2006 .

\section{DuPont Analysis of Arab Bank}

Return on equity for Arab Bank for the study period averages $11.47 \%$ but with a range from $29.12 \%$ in 2000 to $10.76 \%$ in 2005 and then to $6.58 \%$ in 2009 . Net profit margin averages $19.82 \%$ with a range of $21.51 \%$ in 2009 to $17.6 \%$ in 2003 and to $12.72 \%$ in 2000 . Total asset turnover averages 0.057 times with a range from 0.074 times in 2000 to 0.044 in 2004 and then to 0.050 times in 2009 . The equity multiplier averages 11.04 times with a range from 13.26 times in 2001 to 5.96 times in 2006 and then to 6.08 in 2009. Return on equity volatility results from significant variability in net profit margin and the equity multiplier. The equity multiplier has decreased steadily from 30.96 times in 2000 to 9.04 times in 2005 and then decreased to 6.08 times in 2009. Net profit margin fluctuates from the low $12.72 \%$ in 2000 to $25.74 \%$ n 2008 and then to $21.51 \%$ in 2009 . Arab Bank, which operates in 30 countries represents the largest Arab banking net work in the world, was effected by the global financial crisis as a reflection of those countries reaction to the crisis. Despite the difficult challenges and changes experienced by the world as a result of that crisis, Arab bank has continued to march, with confidence, down the path of outstanding work that it began more than eighty years ago. The Bank was also able to continue growing under very difficult circumstances, supported by a commitment to its values and historical principles, which enabled the Bank to excel and succeed. The total asset turnover was increased though the world enterprises were suffering from the recent world financial crisis. Arab bank is listed on Amman Stock Exchange (ASE), but as a market leader, Arab Bank $<$ ARBK $>$ is ranked number 1 by market capitalization and represents $28 \%$ of the Amman Stock Exchange.

\section{Summary and Conclusions}

This paper presents a model for the financial analysis of a bank based on the DuPont system of financial analysis as presented in Saunders (2000). The bank return on equity is decomposed into net profit margin, total asset turnover 
and the equity multiplier. This model is applied to Arab Bank of Jordan which is one of the largest banks in Jordan. The DuPont system of financial analysis shows the performance of The Arab Bank over the years from 2000-2009 and the impact of the world financial crisis that hit the region in the recent years. Though there was a negative impact of the recent financial crisis on most banks of the world but this impact hit slightly the performance of Arab Bank of Jordan.

Beginning with 2000, Arab Bank had high return on equity as well as high equity multiplier as compared to other years under study. After 2001 until 2008, the financial performance of Arab Bank is relatively steady and reflects minimal volatility in the return on equity components except for the year 2009 the ratio declined due to the impact of the recent financial crisis. Net profit margin and total asset turnover exhibit relative stability for the period from 2001 to 2009. The equity multiplier also show almost stable indicators for the period from2001-2005 and the ratios declined from 2006-2009 which indicates that the Arab bank had less financial leverage in the recent years, which means the bank is relying less on debt to finance its assets. Net profit reached approximately 25.74 percent with an average 19.82 percent, total asset turnover of about 7.39 percent and an average of 5.71 percent, and the equity multiplier leveled out at about 30.96 percent with average of 11.04 percent.

\section{References}

Arab bank of Jordan, Annual Reports.ASE. (2000-2010).

Brigham, E. F., \& Houston, J. F. (2001). Fundamentals of financial management, concise Third Edition, Harcourt Publishers.

Cole, D. (1973). Return on equity model for banks. The Bankers Magazine, Spring.

Dietrich, J. K. (1996). Financial services and financial institutions. Prentice Hall.

Estrella, A., Sangkyun, P., \& Stavros, P. (2000). Capital ratios as predictors of bank failure. Economic policy review, Federal Reserve Bank of New York, 6,2, 33-52.

Harm, C. (2002). Bank management between shareholders and regulators. SUERF Studies, No. 21. Vienna: SUERF. Hawawini, G., \& Viallet, C. (1999). Finance for executives, South-Western College Publishing.

Kose, J., \& Yiming, Q. (2003). Incentive features in CEO compensation in the banking industry. - Federal Reserve Bank of New York Economic policy review, 9, 1, 107.

Liesz, T. (2002). Really modified Du Pont analysis: Five ways to improve return on equity. Proceedings of the SBIDA Conference. n.p.

Little, P. L., Mortimer, J. W., Keene, M. A., Henderson, L. R. (2009). Evaluating the effect of recession on retail firms' strategy using DuPont method: 2006-2009. Journal of Finance and Accountancy, 2-3.

Macay, J. R., \& O’Hara, M. (2003). The corporate governance of banks. Federal Reserve Bank of New York Economic policy review, 9, 1, 91-107

Nissim, D., \& Penman, S. (2001). Ratio analysis and valuation: From research to practice. Review of accounting studies, 6, 109-154. http://dx.doi.org/10.1023/A:1011338221623

Palepu, K., \& Healy, P. (2008). Business analysis and valuation: Using financial statements (Fourth edition). Mason, OH: Thomson Southwestern.

Pratt, J., \& Hirst, D. (2008). Financial reporting for managers: A value-creation perspective. New York, NY, Wiley.

Renee, A., \& Hamid, M. (2003). Is corporate governance different for bank holding companies? Economic Policy Review, Federal Reserve Bank of New York, issue Apr, 123-142.

Saunders, A. (2000). Management of financial institutions, Third edition, McGraw Hill.

Soliman, M. (2004). Using industry-adjusted Du Pont analysis to predict future profitability and returns. Ph.D. dissertation, University of Michigan. http://dx.doi.org/10.2308/accr.2008.83.3.823

Soliman, M. (2008). The use of Du Pont analysis by market participants. The Accounting Review, 83(3), 823-853.

Sundararajan, V., Enoch, C., San José, A., Hilbers, P., Krueger, R., Moretti, M., \& Slack, G. (2002). Financial soundness indicators: Analytical aspects and country practices. IMF occasional paper, No. 212. Washington DC: IMF. 
Vensel, V. (2001). Estonian banking system performance, 1994-2000. In: Vensel, V., \& Wihlborg, C., eds. Estonia on the threshold of the European Union: Financial sector and enterprise restructuring in the changing economic environment. Tallinn: Tallinn Technical University, 23-43.

Vensel, V. (1997). Banking system development in Estonia. In: Kowalski, T., ed. Financial reform in emerging market economies, Poznan. Poznan University of Economics,141-164.

Table 1. Arab Bank of Jordan Financial Statements (2000-2009) (In Thousand Jordanian Dinars "000")

\begin{tabular}{|c|c|c|c|c|c|c|c|c|c|c|c|}
\hline Income Statement - Income & 2000 & 2001 & 2002 & 2003 & 2004 & 2005 & 2006 & 2007 & 2008 & 2009 & Average \\
\hline Interest Income & 894257 & 775153 & 585661 & 499583 & 539934 & 723986 & 931750 & 1183122 & 1128629 & 916739 & 817881 \\
\hline Non Interest Income and Gains & 129380 & 149916 & 149157 & 183509 & 199460 & 225741 & 194756 & 217951 & 270627 & 245732 & 196623 \\
\hline Income Statement Expenses & & & & & & & & & & & Average \\
\hline Interest Expenses & -632790 & -506754 & -325469 & -251086 & -262550 & -368730 & -464662 & -640236 & -576012 & -398367 & -442665 \\
\hline Provision for Bad Loans & -34415 & -41511 & -31435 & -35848 & -24853 & -6746 & -23202 & -11341 & -6620 & -85499 & -30147 \\
\hline Overheads & -195364 & -211735 & -222765 & -246878 & -266723 & -320103 & -309371 & -332778 & -346816 & -353942 & -316042 \\
\hline Income Tax & -30868 & -25869 & -24949 & -26745 & -39844 & -54056 & -65994 & -82062 & -89668 & -74624 & -51468 \\
\hline Net Income & 130200 & 139200 & 130200 & 120200 & 144200 & 200092 & 263277 & 334656 & 360174 & 250039 & -207224 \\
\hline Balance Sheet- Assets & 2000 & 2001 & 2002 & 2003 & 2004 & 2005 & 2006 & 2007 & 2008 & 2009 & Average \\
\hline Cash & 1406023 & 1629226 & 1735788 & 2103607 & 2253477 & 2044984 & 1940964 & 2894720 & 3026127 & 4004819 & 2303974 \\
\hline Customer Loans & 3336626 & 3755995 & 3864377 & 3770014 & 3444403 & 3683586 & 4321512 & 3507125 & 3263567 & 2782746 & 3572995 \\
\hline Securities and Deposits & 8673176 & 8766706 & 8719974 & 9215561 & 10688100 & 10573816 & 11642611 & 14258893 & 15846624 & 15756920 & 11414238 \\
\hline Fixed and Other Assets & 429279 & 396908 & 394014 & 387930 & 400048 & 513418 & 535051 & 559293 & 614684 & 555006 & 478563 \\
\hline Total Assets & 13845104 & 14548835 & 14714153 & 15477112 & 16786028 & 16815804 & 18440138 & 21220031 & 22751002 & 23099491 & 17769770 \\
\hline Balance Sheet -Liabilities & & & & & & & & & & & Average \\
\hline Deposits & 12342462 & 12974264 & 12966576 & 13599191 & 14582887 & 14366500 & 14870546 & 17161380 & 18638502 & 18777745 & 15028005 \\
\hline Other Liabilities & 1055480 & 398976 & 461551 & 444395 & 602762 & 589674 & 475644 & 510657 & 532546 & 520540 & 559223 \\
\hline Shareholder Funds & 447162 & 1096932 & 1286026 & 1433526 & 1600379 & 1859630 & 3093948 & 3547994 & 3579954 & 3801206 & 2174676 \\
\hline Total Liabilities \& Shareholders Equities & 13845104 & 14548835 & 14714153 & 15477112 & 16786028 & 16815804 & 18440138 & 21220031 & 22751002 & 23099491 & 17769770 \\
\hline
\end{tabular}


Table 2. Arab Bank Ratio Computation

\begin{tabular}{|c|c|c|c|c|c|c|c|c|c|c|c|}
\hline Income Statement Items & 2000 & 2001 & 2002 & 2003 & 2004 & 2005 & 2006 & 2007 & 2008 & 2009 & Average \\
\hline Interest Expenses & $61.82 \%$ & $54.78 \%$ & $44.29 \%$ & $36.76 \%$ & $35.51 \%$ & $38.80 \%$ & $41.25 \%$ & $45.70 \%$ & $41.17 \%$ & $34.27 \%$ & $34.27 \%$ \\
\hline Provision for Loan Facilities & $3.36 \%$ & $4.49 \%$ & $4.28 \%$ & $5.25 \%$ & $3.36 \%$ & $0.72 \%$ & $2.06 \%$ & $0.81 \%$ & $0.47 \%$ & $7.35 \%$ & $3.22 \%$ \\
\hline Staff and Other Overheads & $19.09 \%$ & $22.89 \%$ & $30.32 \%$ & $36.48 \%$ & $36.24 \%$ & $33.70 \%$ & $27.46 \%$ & $23.75 \%$ & $24.79 \%$ & $30.45 \%$ & $28.52 \%$ \\
\hline Income Tax & $3.02 \%$ & $2.80 \%$ & $3.40 \%$ & $3.92 \%$ & $5.39 \%$ & $5.70 \%$ & $5.86 \%$ & $5.86 \%$ & $6.41 \%$ & $6.42 \%$ & $4.88 \%$ \\
\hline Net Income & $12.72 \%$ & $15.05 \%$ & $17.72 \%$ & $17.60 \%$ & $19.50 \%$ & $21.07 \%$ & $23.37 \%$ & $23.89 \%$ & $25.74 \%$ & $21.50 \%$ & $19.82 \%$ \\
\hline Total Income Statement & $100.00 \%$ & $100.00 \%$ & $100.00 \%$ & $100.00 \%$ & $100.00 \%$ & $100.00 \%$ & $100.00 \%$ & $100.00 \%$ & $100.00 \%$ & $100.00 \%$ & $100 \%$ \\
\hline Balance Sheet Assets & 2000 & 2001 & 2002 & 2003 & 2004 & 2005 & 2006 & 2007 & 2008 & 2009 & Average \\
\hline Cash & $10.16 \%$ & $11.20 \%$ & $11.80 \%$ & $13.59 \%$ & $13.42 \%$ & $12.16 \%$ & $10.53 \%$ & $13.64 \%$ & $13.30 \%$ & $17.34 \%$ & $12.71 \%$ \\
\hline Customer Loans & $24.10 \%$ & $25.82 \%$ & $26.26 \%$ & $24.36 \%$ & $20.52 \%$ & $21.91 \%$ & $23.44 \%$ & $16.53 \%$ & $14.34 \%$ & $12.05 \%$ & $20.93 \%$ \\
\hline Securities, Net & $62.64 \%$ & $60.26 \%$ & $59.26 \%$ & $59.54 \%$ & $63.67 \%$ & $62.88 \%$ & $63.14 \%$ & $67.12 \%$ & $69.65 \%$ & $68.21 \%$ & $63.64 \%$ \\
\hline Fixed and Other Assets & $3.10 \%$ & $2.73 \%$ & $2.68 \%$ & $2.51 \%$ & $2.38 \%$ & $3.05 \%$ & $2.90 \%$ & $2.64 \%$ & $2.70 \%$ & $2.70 \%$ & $2.71 \%$ \\
\hline Total Assets & $100.00 \%$ & $100.00 \%$ & $100.00 \%$ & $100.00 \%$ & $100.00 \%$ & $100.00 \%$ & $100.00 \%$ & $100.00 \%$ & $100.00 \%$ & $100.00 \%$ & $100.00 \%$ \\
\hline Balance Sheet- Liabilities & 2000 & 2001 & 2002 & 2003 & 2004 & 2005 & 2006 & 2007 & 2008 & 2009 & Average \\
\hline Deposits & $89.15 \%$ & $89.18 \%$ & $88.12 \%$ & $87.87 \%$ & $86.88 \%$ & $85.43 \%$ & $80.64 \%$ & $80.87 \%$ & $81.92 \%$ & $81.29 \%$ & $85.14 \%$ \\
\hline Other Liabilities & $7.62 \%$ & $2.74 \%$ & $3.14 \%$ & $2.87 \%$ & $3.97 \%$ & $3.51 \%$ & $2.58 \%$ & $2.41 \%$ & $2.34 \%$ & $2.25 \%$ & $3.34 \%$ \\
\hline Shareholders Equities & $3.23 \%$ & $7.54 \%$ & $8.74 \%$ & $9.26 \%$ & $9.53 \%$ & $11.05 \%$ & $16.79 \%$ & $16.72 \%$ & $15.74 \%$ & $16.46 \%$ & $11.51 \%$ \\
\hline Total Liabilities \& Shareholders Equities & $100.00 \%$ & $100.00 \%$ & $100.00 \%$ & $100.00 \%$ & $100.00 \%$ & $100.00 \%$ & $100.00 \%$ & $100.00 \%$ & $100.00 \%$ & $100.00 \%$ & $100 \%$ \\
\hline DuPont Ratios & 2000 & 2001 & 2002 & 2003 & 2004 & 2005 & 2006 & 2007 & 2008 & 2009 & Average \\
\hline Net Profit Margin (NPM) & $12.72 \%$ & $15.05 \%$ & $17.72 \%$ & $17.60 \%$ & $19.50 \%$ & $21.07 \%$ & $23.37 \%$ & $23.89 \%$ & $25.74 \%$ & $21.51 \%$ & $19.82 \%$ \\
\hline Asset Utilization (TAT) & $7.39 \%$ & $6.36 \%$ & $4.99 \%$ & $4.41 \%$ & $4.40 \%$ & $5.65 \%$ & $6.11 \%$ & $6.60 \%$ & $6.15 \%$ & $5.03 \%$ & $5.71 \%$ \\
\hline Equity Multiplier (EM) & $30.96 \%$ & $13.26 \%$ & $11.44 \%$ & $10.80 \%$ & $10.49 \%$ & $9.04 \%$ & $5.96 \%$ & $5.98 \%$ & $6.36 \%$ & $6.08 \%$ & $11.04 \%$ \\
\hline Return on Equity (ROE) & $29.12 \%$ & $12.69 \%$ & $10.12 \%$ & $8.38 \%$ & $9.01 \%$ & $10.76 \%$ & $8.51 \%$ & $9.43 \%$ & $10.06 \%$ & $6.58 \%$ & $11.47 \%$ \\
\hline
\end{tabular}

Source: Calculated from the Arab Bank Annual Financial Reports 2000-2009

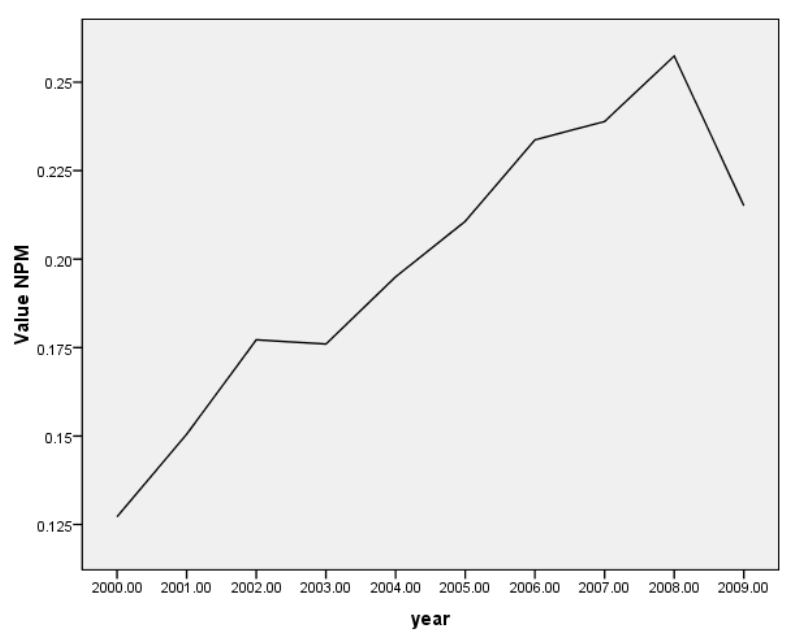

Graph 1. Arab Bank of Jordan 


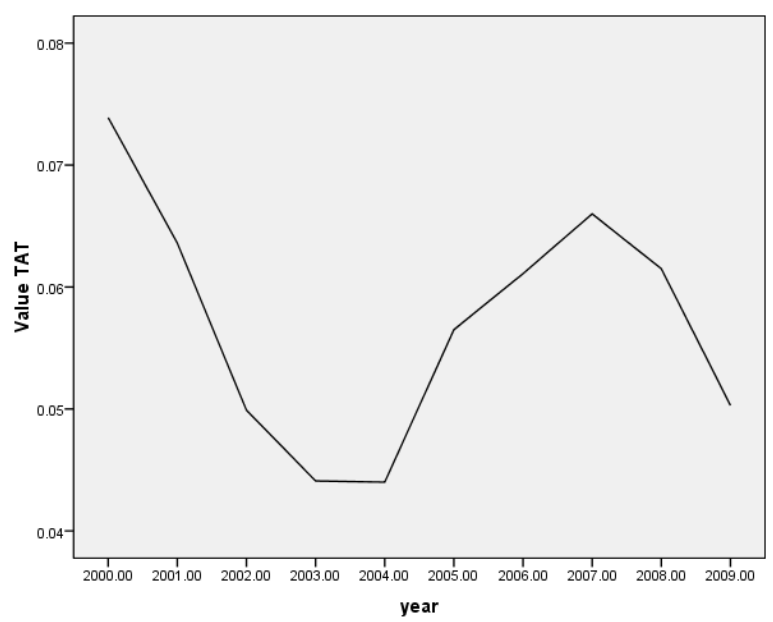

Graph 2. Arab Bank of Jordan

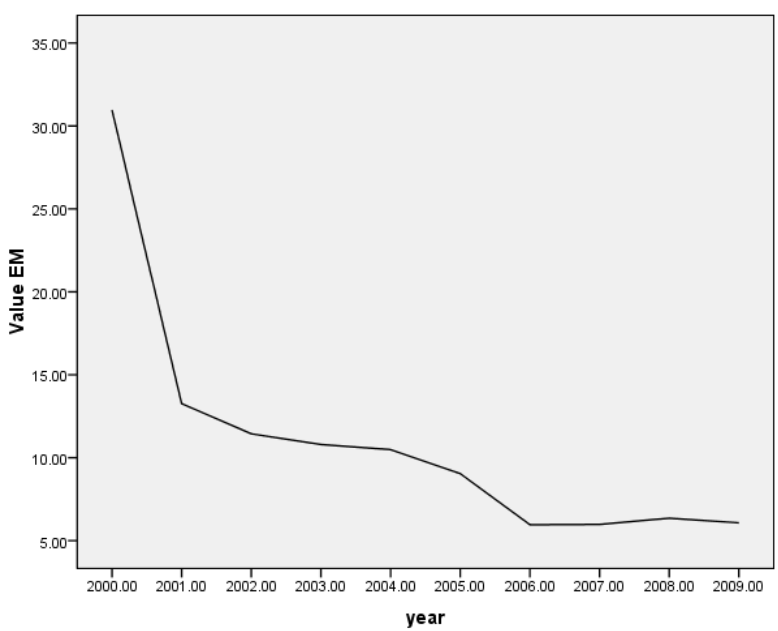

Graph 3. Arab Bank of Jordan

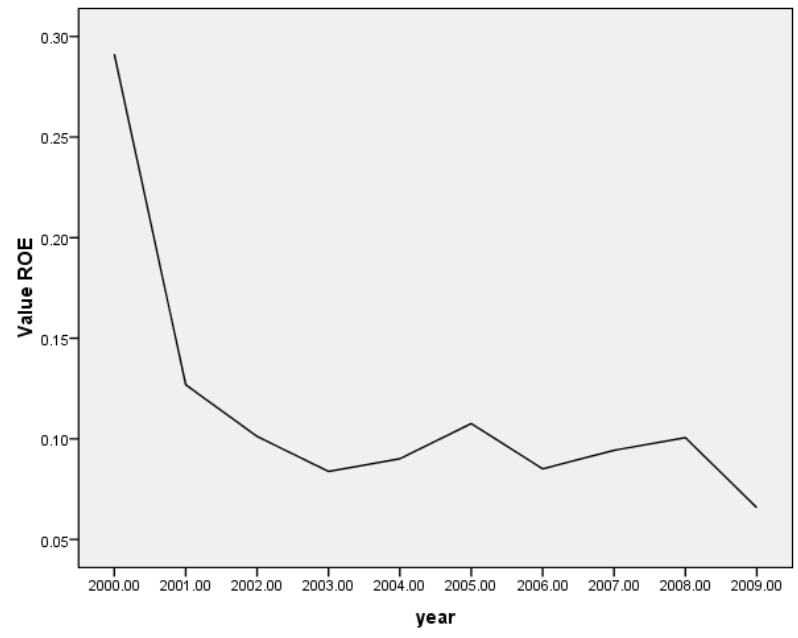

Graph 4. Arab Bank of Jordan 